\begin{abstract}
Summary: Around the world, fashion design programs are reexamining their long-held academic philosophies in order to respond to several circumstances. These included a highly accelerated and globalized industry, the industry's demand for new graduate attributes, and an evolving student generation. Fashion design education is attempting to address these challenges by placing greater emphasis on "design thinking" and conceptual processes that will produce designers who can understand broader global contexts, innovate fashion design, and rethink business systems. These changes are leading the fields of Academia and Industry to question the future role of the fashion designer. As a leader in art and design education, Parsons the New School for Design in New York City is questioning the future of the fashion designer and the fashion industry through ongoing conversations and evolving academic philosophies. It is in this environment of the changing academic landscape in both Fashion Academia and Industry, and the importance of discussing fashion in broader contexts, that this journal is presented. The Parsons contributors represent each of the five Schools and were asked to contribute papers through their own unique discipline's lens. The papers are rich in fashion context and include areas of business and entrepreneurship, history, student development, architecture, craft, pedagogy, and, of course, fashion education.
\end{abstract}

Keywords: business - design thinking - designer - education - fashion design - innovation - pedagogy - student development.

[Summaries in spanish and portuguese at pages 111-112]

(*) Parsons alumnus ('94), Steven began teaching in 1998. Currently is an Assistant Professor in the Parsons BFA Fashion Design Program and served as its Program Director from 2007-2011. He completed his M.S. Ed. at Bank Street College of Education and plans to pursue $\mathrm{PhD}$ studies in Education. [See full version at page 207]

Around the world, fashion design programs are reexamining their long-held academic philosophies in order to respond to several circumstances. These included a highly accelerated and globalized industry, the industry's demand for new graduate attributes, and an evolving student generation. Fashion design education is attempting to address these challenges by placing greater emphasis on "design thinking" and conceptual processes 
that will produce designers who can understand broader global contexts, innovate fashion design, and rethink business systems.

Globalization and advanced technologies are playing a pivotal role in reshaping the fashion industry. Our world's increased levels of consumption are radically increasing production; in many areas of the world, material needs being met and this is leading design to be driven not by need, but by the designers' attempt to embed emotion, meaning, and community into their work. As Daniel Pink (2005) states in his book A Whole New Mind: Why Right Brainers Will Rule the Future, designers must increasingly become "story tellers" who area able to attract an audience with emotionally compelling design.

These changes are leading the fields of Academia and Industry to question the future role of the fashion designer. How can Academia best prepare its graduates? What is the future of the fashion industry? In what ways can Education and Industry collaborate? How can business systems be improved through the formation of unexpected partnerships between the fashion industry and previously unrelated disciplines? What does it mean to be a fashion designer in the 21 st century?

These questions have led to an overhaul of curricula in many American fashion design schools, previously rooted in the Bauhaus principles that emphasized a vocational pedagogy in which students learned by making. To prepare graduates for today's sophisticated, accelerated, and highly volatile global industry, long-held academic philosophies are slowly giving way to broader curricula that promote "design thinking," elevated conceptual processes, and overlaps into other disciplines for inter- and trans-disciplinary thinking. Globalization is a particularly powerful driver for reshaping fashion design education and professional practice; it will be essential for fashion designers to become educated in the nuances of emerging markets, sub-cultures, available resources, and technologies if they are to improve and innovate current fashion industry practices. To support this new curricula, many schools are creating programs increasingly influenced by issues of ethics, philosophy, technology, global systems, business studies, and environmental issues. By doing so, design educators prepare their graduates for success in the hyper-globalized industry and an ability to synthesize their fashion practice with other disciplines. However, this hyper-globalization has led some designers to counter this future by creating small-scale fashion practices that often operate on the local level. However, in both scenarios, the future designer will need broader thinking that transcends mere design and aesthetics if they are to operate a sustainable practice.

The ability to collaborate with other disciplines will be enormously beneficial for fashion designers and the industry because it will allow them to evolve and improve outdated methods of designing, producing, and showcasing fashion design. By cross-fertilizing fashion design with such areas as science, business, and education, the designers' creative processes are expanded, new practices and methodologies are able to be tested and applied, and the creators' reflective processes increase due to the addition of alternative perspectives. Given the increasing scale and impact the fashion industry has on the world's economies and environments, it can no longer be the siloed vocation it once was. This impact has led to the growing scholarship in fashion studies; this is shown by the increasing numbers of international graduate and doctoral programs in fashion design, museum departments and exhibitions, and academic journals dedicated to the examination of what fashion 
means to our world's cultural landscapes. To improve and strengthen the fashion practices, Academia and Industry must partner and involve other disciplines.

\section{The Institution}

As a leader in art and design education, Parsons the New School for Design in New York City is questioning the future of the fashion designer and the fashion industry through ongoing conversations and evolving academic philosophies. Parsons contains five Schools: The School of Fashion (SoF); The School of Constructed Environments (SCE); The School of Art, Design, History, and Theory (ADHT); The School of Arts, Media, and Technology (AMT); and The School of Design Strategies (SDS). Within each School, graduate and undergraduate programs house disciplines that relate to one another. For example, in AMT, the programs of Fine Arts and Illustration are contained, SCE offers graduate and undergraduate degrees in Architecture and Interior Design, and SoF offers programs in Fashion Design and Fashion Marketing. While these Schools offer students their own areas of study, broader philosophies in art and design education are influencing their programs' academic framework and curricula in order to contextualize each student's area of study; the importance for this breadth (and depth) has even led to the creation of a graduate-level interdisciplinary program and undergraduate course pathways that allow students to experience multiple Schools, thus supporting the belief that "design thinking" and cross-disciplinary partnerships may reshape design education and practice.

\section{The Journal}

It is in this environment of the changing academic landscape in both Fashion Academia and Industry, and the importance of discussing fashion in broader contexts, that this journal is presented. The Parsons contributors represent each of the five Schools and were asked to contribute papers through their own unique discipline's lens. The papers are rich in fashion context and include areas of business and entrepreneurship, history, student development, architecture, craft, pedagogy, and, of course, fashion education.

Steven Faerm in The School of Fashion (SoF) presents a year-long study that examines the transitional experience of the fashion design graduate as they move from academia into professional practice. Due to the changes occurring in fashion design education, and an industry that is becoming increasingly uncertain, the author addresses concerns for the challenges experienced by these "emerging adults" when they enter the Industry. By researching society's relationship with design and consumption, fashion design education, the developmental attributes of young adults, mentorship, the role of internships during students' education, and undergraduates' preparation for the professional world, new insights are gained. The author then provides several suggestions for how fashion education may evolve in order to better support fashion design graduates. The author contents that awareness for the critical role the transition experience plays must always remain connected to an academic institution's philosophy, program design, and curricula; 
this awareness will produce a more successful student and alumni body who are increasingly engaged and committed to the profession due to their fluid and positive transition from the academic environment into the fashion design profession.

Aaron Fry and Reina Arajki in The School of Design Strategies (SDS), and Steven Faerm in The School of Fashion ( $\mathrm{SoF}$ ) present a co-authored paper examining the increasing numbers of fashion design graduates who are launching their own small-scale fashion business practices directly upon graduation. Rather than pursuing traditional corporate modes of practice, these graduates are electing to direct their professional ambitions towards smaller business entrepreneurship. These professional interests will require fashion design programs to adopt advanced business coursework and new academic models that support these ambitions alongside the traditional fashion design pedagogy. The authors examined the New York Fashion Industry, market segmentation, and undergraduate fashion design education to provide context for the small fashion business at the local level. An archetype dubbed the "Incidental Fashion Entrepreneur" (IFE) was created "in order to understand the underlying motivations for young fashion designers who elect to become small business entrepreneurs." The authors' study concludes with an overview of the key themes that emerged from the qualitative research; the goal of the authors' proposed themes is to provide new insights and strategies for future (or existing) fashion entrepreneurs, fashion design program directors who are evolving their curricula, and students who plan to launch a small-scale fashion business directly following their fashion design studies.

Robert Kirkbride in The School of Constructed Environments (SCE) examines fashion through the unique lens of architecture. The author contents that the bonds of fashion and the constructed environment are deep, tectonically and culturally. In medieval spiritual meditation, the mind was built in the image of a walled city whose buildings were "clothed" by moral understanding; in Renaissance Florence, the philosopher-doctor Marsilio Ficino recommended that planetary colors be worn and applied as architectural ornament to assist in contemplation and judgment. Linked etymologically, our habits (abitudine), clothing (abito), and buildings (abitazione) are the revealing ornaments of our minds, preparing us for everyday life. The array of artifacts and accessories that extend from clothing to shelter furnishes the imagination with ingredients for personal and shared memory and identity. The author's paper considers several historical and contemporary examples.

Lauren Downing-Peters in The School of Art, Design, History, and Theory (ADHT) is a recent graduate and faculty member within the new MA Fashion Studies Program at Parsons. Following her co-authorship of a recent article titled Fashion Studies at Parsons: What is it Anyways, the author presents a paper that describes the importance of this relatively new field of scholarship; she states that "fashion is a tremendously expansive category that encompasses everything from matters of dress and personal adornment to the complex ways the so-called 'fashion system' operates both locally and globally." It is with this understanding of the field's interdisciplinary and boundless nature that the author positions her paper for the reader; the well rounded fashion studies scholar must 
at once be a historian, a sociologist, and a cultural theorist as well as a sound writer, a competent ethnographer, and a gifted researcher. The author's paper provides an overview of the academic discipline and a reflection of her own pedagogical challenges experienced during her first semester teaching Fashion Studies at Parsons. It is through her paper that a dialogue between Fashion Studies scholars, as well as other academics who work and research in interdisciplinary fields, is encouraged in order to position fashion in more formalized scholarship.

Melinda Wax in The School of Arts, Media, and Technology (AMT) investigates fashion design education in a highly unique manner by discussing the importance of "making". As design education questions how to evolve, innovate, and strengthen its graduates, many are attempting to build a "knowledge-based economy" that Daniel Pink (2005) describes in his book A Whole New Mind: Why Right-Brainers Will Rule the Future. In this paper, the author argues for "a renewed cultivation of manual competence in balance with the digital technologies bridging between methods which blend hands and minds into one effort/ exercise with immediate results versus methods which take time and patience, but result in a multi-faceted and life-long learning experience."

Resumen: Alrededor del mundo, los programas de diseño de moda están rexaminando sus filosofías académicas de larga data con el fin de responder a distintas circunstancias. Esto incluye una industria altamente acelerada y globalizada, la demanda por parte de la industria de nuevos atributos en los graduados y una generación de estudiantes en evolución. La enseñanza del diseño de moda está tratando de hacer frente a estos retos poniendo un mayor énfasis en el "pensamiento de diseño" y en los procesos conceptuales que generarán diseñadores que puedan entender los contextos globales más amplios, innovar en el diseño de moda, y repensar los sistemas de negocio. Estos cambios están llevando tanto a las universidades como a la industria a replantearse el papel futuro del diseñador de moda. Como líder en las expresiones artísticas y en la enseñanza del diseño, la Parsons New School for Design de Nueva York está cuestionando el futuro del diseñador de moda y el de la industria de la moda a través del diálogo permanente y la evolución de la filosofía académica. Es en este contexto de cambio en el escenario académico, tanto en la formación en diseño de moda como en la Industria, y la necesidad de llevar el debate sobre la moda a contextos más amplios, que se presenta este Cuaderno. Los autores de Parsons representan a cada una de las cinco escuelas de diseño y sus artículos abordan esta problemática a través de la mirada específica de su propia disciplina. Los papers profundizan en el contexto de la moda e incluyen temáticas vinculadas a los negocios y emprendimientos, la historia, el desarrollo del estudiante, la arquitectura, la artesanía, la pedagogía y, por supuesto, la enseñanza del diseño de moda.

Palabras clave: desarrollo del estudiante - diseñador - diseño de moda - educación - innovación - negocio - pedagogía - pensamiento de diseño. 
Resumo: Ao redor do mundo, os programas de design de moda estão re-examinando suas antigas filosofias acadêmicas com o fim de responder a diferentes circunstancias. Isto inclui uma indústria altamente acelerada e globalizada, a demanda por parte da indústria de novos atributos nos graduados e uma geração de estudantes em evolução. O ensino do design de moda está procurando fazer frente a estes desafios pondo um maior ênfase no "pensamento de design" e nos processos conceptuais que irão gerar designers que possam entender os contextos globais mais amplos, inovar no design de moda, e re-pensar os sistemas de negócio. Estas mudanças estão levando tanto às universidades como à indústria a se re-enfocar o papel futuro do designer de moda. Como líder nas expressões artísticas e no ensino do design, a Parsons New School for Design de Nova York está questionando o futuro do designer de moda e o da indústria da moda através do diálogo permanente e a evolução da filosofia acadêmica. É neste contexto de mudança no cenário acadêmico, tanto na formação em design de moda como na Indústria, e a necessidade de levar o debate sobre a moda a contextos mais amplos, que se apresenta este Caderno. Os autores da Parsons representam a cada uma das cinco escolas de design e seus artigos abordam esta problemática através da mirada específica da sua própria disciplina. Os papers aprofundam no contexto da moda e incluem temáticas relativas aos negócios e empreendimentos, a história, o desenvolvimento do estudante, a arquitetura, o artesanato, a pedagogia, e, certamente, a educação em moda.

Palavras chave: desenvolvimento do estudante - design de moda - designer - educação inovação - negócio - pedagogia - pensamento de design. 